\title{
Krzysztof Sawicki, Diady, kliki, gangi. Młodzież nieprzystosowana społecznie w perspektywie współczesnej pedagogiki resocjalizacyjnej [Dyads, Cliques, Gangs. Juvenile Offenders from the Perspective of Contemporary Social Rehabilitation], Wyd. Impuls, Kraków 2018, pp. 273
}

Educating young people prepared for the future, and at the same time well-established in the present, is not only a matter of the family, school, workplace or youth club. It is also determined by the whole environment that surrounds young people. Only "living” activity and strong attractiveness of non-formalized structures allow to give a sense of life to everything that the young man has found out, learned in his family home and at school. Already in 1957, Jan Szczepański wrote about the necessity of liberating social forces in the form of admitting all organizations and entrusting them with some matters in the field of social welfare, some cultural and educational matters (Szczepański, 1957). We do often forget (what is valid even today) about these social forces, constantly stressing economic difficulties and lack of money. It is forgotten that people in social life are looking not only for income, but above all for the possibility of pleasant coexistence, seeking recognition and, above all, their place in the world around them that will give them a sense of security. Has today's world forgotten that only "normal social conditions" create "normal people"? Because only when the society shows its members clear prospects for their future and this real perspective - ensuring the possibility of reaching recognition, respect, job satisfaction and a sense of security, there can be identification of the individual with the entirety, identification of their life goals with the goals of the society.

Departament of Social Prevention and Rehabilitation, Educational and Artistic Faculty,Jan Kochanowski’s University in Kielce, Poland, E-MAIL: aneta.skuza@ujk.edu.pl. 
This crisis, which young people in some environments are experiencing, forces us to see the situation in which it operates, and in which there are often no constructive forms for its dynamism, for its vital force, and also for the social power it represents.

Is this just a problem of the present? Certainly not. It is enough to reach for the work of one of the masters, and more precisely one of the creators of the Polish rehabilitation thought of Czesław Czapów. In 1959, he published his book titled Czy Johnny stanie się gangsterem? Uwagi o metodach walki z przestępczościq [Will Johnny Become a Gangster? Remarks on Methods of Fighting Youth Crime] (Czapów, 1959), in which he emphasized that controlling the social space criminal youth functions is extremely difficult, perhaps even more difficult than controlling outer space. But noticing the successes of Makarenko, Chazal, we should realize that there is no such difficult rehabilitation work that, could be said, is not worth taking. It was him who, many years ago, emphasized that in this field integration and understanding of the society is very important, a kind of "social atmosphere" enabling a series of activities, because the problem of "dangerous streets" is neither easy nor hopeless. Therefore, it is a complex phenomenon, but it is possible to investigate, interpret it. What he also convinced us about in his next book titled Niebezpieczne ulice. Źródła chuligaństwa. Materiały i refleksje [Dangerous Streets. At the Source of Hooliganism. Materials and Reflections] published together with Stanisław Manturzewski (Czapów \& Manturzewski, 1960).

We are also convinced by the author of the reviewed book - Krzysztof Sawicki, who in a chapter "Instead of intro-rebellious, evil, unwanted" takes us into the world of William Golding's novel titled Lord of the Flies, which in an allegorical way speaks of the fall of a culture created by man. The book describes a group of boys, survivors of a plane crash on a deserted island, whose attempts to organize their own governments and communities had disastrous consequences. The novel describes their gradual plunging into barbarism, thus showing us how children from the so-called "good homes" left alone away from civilization gradually lose human impulses. At the allegorical level, the main theme is the conflict between the pursuit of civilization, harmonious and peacefully governed with clearly defined rules, and the Nietzschean willpower that does not tolerate the opposition of the weaker. At the same time, it is a peculiar description of tensions arising between an individual and the collective showing a group thinking syndrome - between a rational and emotional reaction to a specific situation and between morality and immorality. Thus, this novel shows how this type of tension occurs and how people are gradually subject to their influence. Of course, the approximate vision from 
the novel was only the background of the book being reviewed, but at the very beginning we receive a clear message about what content it will focus on.

The book itself Diady, kliki, gangi. Młodzież nieprzystosowana społecznie w perspektywie współczesnej pedagogiki resocjalizacyjnej [Dyads, Cliques, Gangs. Juvenile Offenders from the Perspective of Contemporary Social Rehabilitation] consists of three chapters, Codes and a rich juxtaposition of literature, referred to by the author.

The first chapter Założenia badań własnych [The Assumptions of Own Research] is the presentation of the adopted research assumptions, in which the group, subject, and research objectives were specified (cognitive, theoretical and practical). The adopted theoretical assumptions and specific research objectives became the basis of the main research problem and at the same time made it possible to define specific problems that form a structure reflecting the Urie Bronfenbrenner's ecological system, from which the Author made a specific analysis and presentation of the collected research material. In the following, we learn the methods of data collection, sample selection, and the method (stages) of research organization. In this chapter, the author also made a description of the applied method of analyzing the research material. The qualitative approach adopted in the research work allowed the researcher to adopt an "understanding attitude" when formulating (in conclusion) recommendations consistent with the theoretical approaches depicted in the following chapters but also as the author himself highlights - according to Michael Murray’s thesis: "Qualitative research is an active involvement in social world. This is not just collecting data, but rather developing a practical understanding of the world by including the researcher in a dialectic process ...” (Murray, pp. 585-599).

The second chapter Młodzież problemowa w świetle teorii resocjalizacyjnych [Disorderly Youth in the Perspective of Social Rehabilitation Theories] is a peculiar study of the three phases of adolescence theory development, especially the third phase in opposition to earlier assumptions. This means taking actions for the benefit of young people who will focus not on deficits or dysfunctions (risk factors) but on development potentials (protective factors). Of course, this third approach is a continuation of the threads, especially from the ecological perspective or from the theory of resistance - Resilience. What the author particularly pays attention to is the positive development of young people - PYD (Positive Youth Development whose essence is a "kind of symbiosis" of the world of science and politics in order to support the development of individuals during adolescence. The author introduces us in detail through the definition of PYD, including the concept of “five Cs” (R.M. Lerner et al.); Benson’s proposal focusing on two 
categories: external and internal resources; after the inclusion of R.F. Catalano and his research team. At the same time, we will be introduced to the project based on PYD, including a comprehensive model of activities in the environment - the CREATE project. In the further part of this chapter, we learn about the exhaustive characterization of the juvenile delinquency syndrome, including the ecosystem perspective of interpretation and analysis of non-compliant behaviour. Here, the author puts special emphasis on the approach of the aforementioned Urie Bronfenbrenner, which is indeed close to the developed in Poland concepts of the local environment as a preventive and rehabilitation system of Stanisław Kowalski and socializing rehabilitation of Wiesław Ambrozik. In connection with the subject of research undertaken by the author in his analysis, he also focused on the category of informal youth groups, thus bringing us closer to the specifics of peer relationships - mysterious ones - dyads, cliques and gangs included in the title. In this chapter, the Good Lives Model (GLM) is also presented in detail. This is a theoretical model that is closely related to Risk-Need-Responsivity (RNR), and in the literature of the subject it is quite poorly described (Barczykowska, Dzierżyńska-Breś, Muskała, 2015, pp. 41-49). It is explained as a "model of a good life", described for the first time by Tony Ward and Claire A. Stewart in relation to the perpetrators of sex crimes (Ward, Stewart, 2003, p. 353). Thus, the Author provides us with detailed information on GLM, its theoretical foundations, objectives, and implemented activities, while also showing us critical voices expressed against GLM, as well as those that emphasize its legitimacy in relation to the proposed resocialization interactions.

Nieletni-rówieśnicy-środowisko. Młodzież nieprzystosowana społecznie w świetle badań własnych [Minors-Peers-Environment. Juvenile Offenders in the Light of Their Own Research] is the title of the third chapter, which - as the title suggests to us - is an analysis of the collected research material. The author of the statements of the respondents included in the structure reflecting the ecosystem assumptions, gradually presenting its individual components. From the symptoms of juvenile offending we go to the analysis of the world of relationships of minors with peer groups. Attention was also paid to the family situation of underages and neighbourly relations, or with adults with whom the juvenile had contact in their environment (including those who represented various institutions in the place of residence of the respondents). In turn, in Powrót do przeszłości? [Return to the Past?] in this rhetorical question, we find references to juvenile actions that enter into satisfying the need defined as "finding meaning in life". As the author himself emphasizes, the title is also a question about the extent to which the respondents are prepared to return to the home environment, in which they will face the necessity of confronting the whole 
range of risk factors and protective factors they know. This is a rhetorical question as to whether the respondents are willing to change their current lives expressed in the change of place after leaving the social rehabilitation facility.

All these interpretations and generalizations taken from literature became a compass for the author to summarize (Koda [Code]), present conclusions resulting from the conducted research and create proposals for actions aimed at minimizing the phenomenon of juvenile delinquency in Poland.

The assumptions presented in the book are an opportunity to regain the humanistic dimension of social rehabilitation interactions still dominated by pragmatic-conservative thinking. They can bring positive and tangible results not only in the form of deepening the Polish social rehabilitation thought, but above all a real change of the existing, and not fulfilling pedagogues, social and educational doctrine, which we all are both witnesses, participants and perpetrators. Therefore, I recommend this book to all those who are familiar with the problems and challenges of modern rehabilitation.

To sum up, I would like to refer again to the words of the master of Polish rehabilitation thought. In one of the interviews Cz. Czapów said: “The results of the research are to form the basis for the formulation of practical indications for the use of various institutions, how to prevent negative forms of social deviance, and thus what preventive measures to take, and - which is no less important - how to disseminate and strengthen creative and innovative attitudes” (Falkowska, 1969).

It is worth emphasizing that the author perfectly fits into the "trend" of such thinking (Konopczyński, 2014).

\section{References}

Barczykowska, A., Dzierżyńska-Breś, S., \& Muskała, M. (2015 ). Systems of Social Rehabilitation Interactions in England and the United States of America. Poznań: Wyd. UAM.

Czapów, Cz. (1959). Czy Johnny stanie się gangsterem? Uwagi o metodach walki z przestępczościq młodzieży. Warszawa: Wiedza Powszechna.

Czapów, Cz., \& Manturzewski, S. (1960). Niebezpieczne ulice. Źródła chuligaństwa. Materiały i refleksje. Warszawa: Iskry.

Falkowska, W. (1969). Interview with Czapów and Podgórecki, Polityka, 10 (992).

Konopczyński, M. (2014). Pedagogika resocjalizacyjna. W stronę działań kreujących. Kraków: Impuls.

Murray, Implementation: Putting Analyses into Practice. In: U. Flick (Ed.), The Sage Handbook of Qualitative Data Analysis (pp. 585-599), London: Sage.

Szczepański, J. (1957). The attempt to diagnose, Cultural Review, 36 (262).

Ward T., \& Stewart C.A., (2003). The Treatment of Sex Offenders: Risk Management and Good Lives, Professional Psychology: Research and Practice, 34 (4). 